\title{
OCCURRENCE OF MICROPLASTICS AND TRACE METALS IN FISH AND SHRIMP FROM SONGKHLA LAKE, THAILAND DURING THE COVID-19 PANDEMIC
}

\author{
PRADIT, S. $.^{1,2^{*}}-$ NOPPRADIT, P. ${ }^{1,2}-$ GOH, B. P. ${ }^{1,2}-$ SORNPLANG, K. ${ }^{1,2}-$ ONG, M. C. ${ }^{3,4}-$ \\ TOWATANA, P. ${ }^{1,2^{*}}$ \\ ${ }^{I}$ Marine and Coastal Resources Institute, Faculty of Environmental Management, Prince of \\ Songkla University, Songkhla 90110, Thailand \\ ${ }^{2}$ Coastal Oceanography and Climate Change Research Center, Prince of Songkla University, \\ Hat Yai, Songkhla 90110, Thailand \\ ${ }^{3}$ Faculty of Science and Marine Environment, Universiti Malaysia Terengganu, 21030 Kuala \\ Nerus, Terengganu, Malaysia \\ ${ }^{4}$ Ocean Pollution and Ecotoxicology Research Group, Universiti Malaysia Terengganu, 21030 \\ Kuala Nerus, Terengganu, Malaysia \\ *Corresponding authors \\ e-mail: siriporn.pra@psu.ac.th and prawit.t@psu.ac.th
}

(Received 27 ${ }^{\text {th }}$ Aug 2020; accepted $8^{\text {th }}$ Feb 2021)

\begin{abstract}
The study was carried out in the beginning of May, 2020 during the COVID-19 pandemic lockdown period in Thailand. This study reported on the occurrence of microplastic debris in stomachs of fish (Arius maculatus) and shrimps (Parapenaeopsis hardwickii and Metapenaeus brevicornis) from Songkhla Lake. The average occurrences of microplastic pieces per stomach in fish and shrimps according to $10 \%$ digested $\mathrm{KOH}$ reagent were $2.73 \pm 0.15,4.11 \pm 1.12$ and $3.78 \pm 1.12$, respectively. The most common shape of microplastics in fish and shrimp was fiber. Black was the most frequent color found followed by blue, white and red. Microplastic size found in this study ranged from $150 \mu \mathrm{m}$ to $5 \mathrm{~mm}$ and $70 \%$ of microplastic size was less than $1 \mathrm{~mm}$. Five polymer types were reported including polyester, rayon, polyvinyl alcohol, polyethylene and paint. It is worth noting that textile fiber also appeared in stomachs of fish and shrimp. It might have been caused by the fact that during the lockdown period people change their way of life such as doing more laundry thus, releasing more cloth fibers (microplastics) into sewer and lake. This study found anomalous correlation coefficients between the number of microplastic particles in the organisms' stomachs and most of the metal concentrations in their tissues.
\end{abstract}

Keywords: marine debris, polymer, sediment, pollution, FTIR

\section{Introduction}

Marine plastic waste is the origin of microplastics floating in the sea which is considered to be a global marine pollution problem. Plastics are the most common type of marine debris, constituting between $60 \%$ and $80 \%$ of all such waste and over $90 \%$ of all floating particles (Gordon, 2006). Thailand is ranked as the $6^{\text {th }}$ largest in the world for marine waste disposal and therefore, plastic and marine wastes in the marine and coastal ecosystems are critical problems that need to be urgently resolved. Microplastics are of concern especially because they can be ingested by a variety of marine organisms, and possibly be also transferred along the food web (Setälä et al., 2014). This is similar to other environmental problems caused by other types of pollution since 
marine contamination caused by plastic waste and the microplastics floating in the sea definitely generate threat affecting various marine animals.

Microplastics are generally described as small plastic particles that have the common dimension of less than $5 \mathrm{~mm}$ in diameter (Cole et al., 2011; GESAMP, 2015). Microplastics in the marine environment are typically found as pellets, fragments, or fibers and consist of diverse polymers (Hidalgo-Ruz et al., 2012). Some microplastics are denser than seawater and expected to sink to the seafloor. These include polyamide, polyester, polyvinyl chloride and acrylic. Others are lighter than seawater and are often found floating at the surface, including polyethylene, polypropylene, and polystyrene. When plastics enter the ocean, the rate of degradation and persistence of plastics varies by polymer, shape, density, and the purpose of the plastic itself (Eriksen et al., 2014). Over the last 40 years, microplastics have been observed in the stomach contents of marine organisms from invertebrates to mammals (Cole et al., 2014; Jabeen et al.; 2017; Li et al., 2016; Pozo et al., 2019; Rocha-Santos and Duarte, 2015). Ingestion may occur directly due to misidentification of indiscriminate consumption of microplastics for feeding (Ory et al., 2017). These organisms can either ingest microplastics as food, whether unintentionally capturing them while filter or deposit feeding or mistaking them for prey when foraging, or even by ingesting organisms of lower trophic levels containing these particles, i.e. trophic transfer (GESAMP, 2015). Potential consequences of microplastic ingestion include physical damage of the gastrointestinal tract of fish and the creation of a false sensation of satiation, which could result in fish mortality from starvation (Cole et al., 2013; Nadal et al., 2016; Possatto et al., 2011). Microplastic accumulation in organisms has the potential to cause a lot of adverse effects, including mortality, reduction of feeding activity, inhibition of growth and immunity and development of endocrine disruption, oxidative stress, neurotransmission dysfunction and even genotoxicity ( $\mathrm{Lu}$ et al., 2016). Discarded fishing nets and line made of plastic are also a source of microplastics in the environment (Andrady, 2011) due to accidental loss or careless handling by the commercial fishing industry (Gilman, 2015). Over time this material will fragment into smaller pieces due to weathering and biodegradation (Sivan, 2011).

As the toxicity of microplastic is considered based on chemical characteristics, microplastics can absorb the added chemicals (plastic additives) of the production process to get the color and properties of plastic products matching the needs of the market. Furthermore, microplastics have the ability to absorb persistent organic pollutants (POPs) or heavy metals dissolved in seawater. Microplastics and cocontaminants have the potential to affect fishery business and sustainability representing another pressure to already threat fish stocks (Hutchings and Reynolds, 2004). Therefore, microplastics seem like to be the carriers of those toxins into the aquatic animals that consume microplastics. Marine organisms could accumulate heavy metals and their metal concentrations provide a time-integrated degree of metal availability, over long periods of time depending on the metal species (Rainbow, 2002). For example, $\mathrm{Cd}$ may be a carcinogen and $\mathrm{Pb}$ can damage blood circulation (Arnich et al., 2012). The uptake of microplastic and absorbed co-contaminants by caught fish represents a risk to human health as these contaminants may transfer to fish tissue and eventually humans through consumption. Over time, plastic particles contaminate the marine ecosystem and the food chain, including foodstuffs intended for human consumption (Lusher et al., 2013). Accumulation of plastic debris in Thailand's coastal ecosystems has been studied at numerous locations (Pradit et al., 2020). However, 
relatively little is known about microplastics in biota, especially in Songkhla lake, unique lagoon in Thailand and one of 117 lagoonal lakes in the world. Studies of microplastic contamination in Thailand were conducted on economic fish in the lower Gulf of Thailand (Azad et al., 2018) on sessile invertebrates in the eastern coast of Thailand (Thushari et al., 2017), on green mussels sold in fresh markets (Goh et al., 2019) and in sediment from sand and mud beaches in Libong Island, Thailand (Pradit et al., 2020). They found that microplastic contamination was present everywhere.

The Songkhla Lake is a shallow coastal lagoon located in the southern part of Thailand and occupies approximately $1,042 \mathrm{~km}^{2}$. The lake is divided into 4 sections; Thale Noi, Inner Section, Middle Section and Outer Section. The salinity ranges from fresh water in Thale Noi to saline water in the outer section. The Outer Section is connected to the Gulf of Thailand through a deep and narrow outlet at Songkhla City. The Outer Songkhla Lake has several major rivers flowing into the lake such as Samrong, U-tapao and Pawong Canals. Each canal has different activities releasing large amounts of pollutants to the outer Songkhla Lake before flowing into the Gulf of Thailand that is the southern part of the South China Sea. Thus, outer Songkhla Lake acts as a sink receiving wastes from the activities of the upstream area. Important canals in the outer section are a) Samrong Canal, a short canal located in dense population b) Pawong Canal $5.5 \mathrm{~km}$ long and both sides of the canal are covered with the mangrove trees and c) U-taphao Canal, the main source of freshwater with the approximate length of $130 \mathrm{~km}$.

According to the COVID-19 pandemic situation, the first infected person in Thailand was found in January 2020 and led to lockdown and curfew measures throughout the country. Songkhla Province and Songkhla Communicable Disease Committee imposed several orders to solve the problem of extensive and rapid outbreak of the disease, e.g. strictly limiting the numbers of people entering and leaving Songkhla Province, implementing the complete lockdown and curfew measures of the whole province during the disease outbreak (March until May 2020). Thus, all the tourism and other business activities were not allowed. This extensively and intensively affected the entire area of Songkhla Province in all the private and government sectors as well as the livelihoods of people in communities around Songkhla Province and Lake resulting in changing their regular way of life to be the new normal one.

In this study, we investigated microplastic presence in stomachs of catfish species (Arius maculatus) and two shrimp species (Parapenaeopsis hardwickii and Metapenaeus brevicornis) which were widely consumed by the people around Songkhla lake. Catfish (Arius maculatus) is one of the benthic fishes living in Songkhla Lake and it is abundant during the rainy season until the end of the rainy season when the water becomes less salty. Therefore, it can be said that this fish likes to live in water that has relatively low salinity. It prefers to feed on the group of benthic animals such as crustaceans, crabs as its staple food (Angsupanich et al., 2005). Yellow shrimp (Metapenaeus brevicornis) is abundant almost the whole year in the outer lake. Its characteristic is different from other shrimp species in that its skin is yellow and turns strong dark yellow during breeding season. Hence, this small shrimp is sometimes commonly known as yellow shrimp and has economic value especially in Songkhla lake since it has good taste, thin shell, soft texture and is suitable for many types of cooking resulting in good prices and needed by local markets and nearby countries such as Malaysia and Singapore. Spear shrimp (Parapenaeopsis hardwickii) is another type of marine shrimp with a hard, firm shell suitable for being peeled and it is abundant in Songkhla lake. Its shell is quite hard and coarse, only the meat is chopped and then 
crumpled to make shrimp cakes. Thus, both kinds of shrimp and catfish are very valuable and important for fishermen and people around the lake since they can generate quite considerable amount of income for fishermen and are also a very inexpensive source of protein for communities around Songkhla Lake. Therefore, this study aimed to investigate the microplastic accumulation in stomach of common fish (Arius maculatus) and shrimp species (Parapenaeopsis hardwickii and Metapenaeus brevicornis) as well as contamination of trace metals ( $\mathrm{As}, \mathrm{Cd}$ and $\mathrm{Pb}$ ) in their tissues in Songkhla Lake. Furthermore, the studies on the prevention of microplastic and trace metal contamination in some economic aquatic organisms found in outer Songkhla Lake are certainly necessary for providing basic background data and information during the COVID-19 outbreak which will be of great benefit as compared to the data obtained ater COVID-19 pandamic in the future.

\section{Materials and methods}

\section{Sample collection}

A total of 47 samples (fish and shrimp) from 3 species (Arius maculatus, Parapenaeopsis hardwickii and Metapenaeus brevicornis) sold for a human consumption were collected from the local fish market near Songkhla Lake in Songkhla, Thailand (Table 1) in early May 2020 which was a lockdown period of the whole country from COVID-19 pandemic. All the samples were sampling from $2 \mathrm{~kg}$ fish and $1 \mathrm{~kg}$ shrimp per each species. The numbers of samples used in this study are similar to the published articles by various researchers (Cole et al., 2013; De Witte et al., 2014; Kripa et al., 2014; Van Cauwenberghe and Janssen, 2014) Futhermore, these investigated species are commonly consumpted in the southern part of Thailand. All the samples were randomly collected from the local fresh market and transported back to the laboratory of Marine and Coastal Resources Institute at Prince of Songkla University and stored at $-20{ }^{\circ} \mathrm{C}$. Additional sediment and water samples were collected from 3 main canals and one small island in the outer lake namely, U-taphao, Pawong, Samrong Canals and Ko Yoh Island respectively (Fig. 1). Thereafter $\mathrm{pH}$ of sediment and water were determined by $\mathrm{pH}$ meter.

\section{Microplastic recovery from fish and shrimp stomachs}

The total amount of microplastic pieces present in each stomach of the total of 47 fish and shrimp samples was determined and described as followed; fish and shrimp samples were defrosted, measured for weight and length; and then dissected to remove the stomach and digestive tract from the body of each sample. Once the dissected stomachs and digestive tract of samples were digested following the alkaline method (Cole et al., 2014; Ding Jin-Feng et al., 2018) each sample was placed in a $250 \mathrm{ml}$ conical flask. Then $150 \mathrm{ml}$ of $10 \%$ potassium hydroxide $(\mathrm{KOH})$ solution was carefully added before sealing the flask with aluminum foil and left for $12 \mathrm{~h}$ at room temperature for assimilation process. The conical flask was then heated on hotplate at $60{ }^{\circ} \mathrm{C}$ for $12 \mathrm{~h}$ with 1 to $2 \mathrm{~min}$ manual shaking every $2 \mathrm{~h}$ interval to remove all the organic matter. The digested solution was then filtered immediately through a Whatman GF/F filter $(0.7 \mathrm{~mm}$ pore size, $47 \mathrm{~mm}$ diameter) using a Millipore filter set. After that, the filter paper was placed into a clean petri dish and heated in an oven at $50{ }^{\circ} \mathrm{C}$ to complete dryness and then stored in a petri 
dish for visual identification of microplastic debris. Special care was taken to prevent sample contamination during dissection, extraction, sorting and visual identification.

Table 1. Weight (g), length ( $\mathrm{mm}$ ) and habitat of fish and shrimp species

\begin{tabular}{c|c|c|c|c|c}
\hline Common name & Species & n & Weight (g) & Length (mm) & Habitat \\
\hline Catfish & Arius macalatus & 11 & $155.63 \pm 1.21$ & $21.02 \pm 1.17$ & Demersal \\
Spear shrimp & Parapenaeopsis hardwickii & 18 & $7.45 \pm 1.18$ & $8.01 \pm 0.05$ & Pelagic \\
Yellow shrimp & Metapenaeus brevicornis & 18 & $5.01 \pm 0.44$ & $7.16 \pm 1.15$ & Pelagic \\
\hline
\end{tabular}
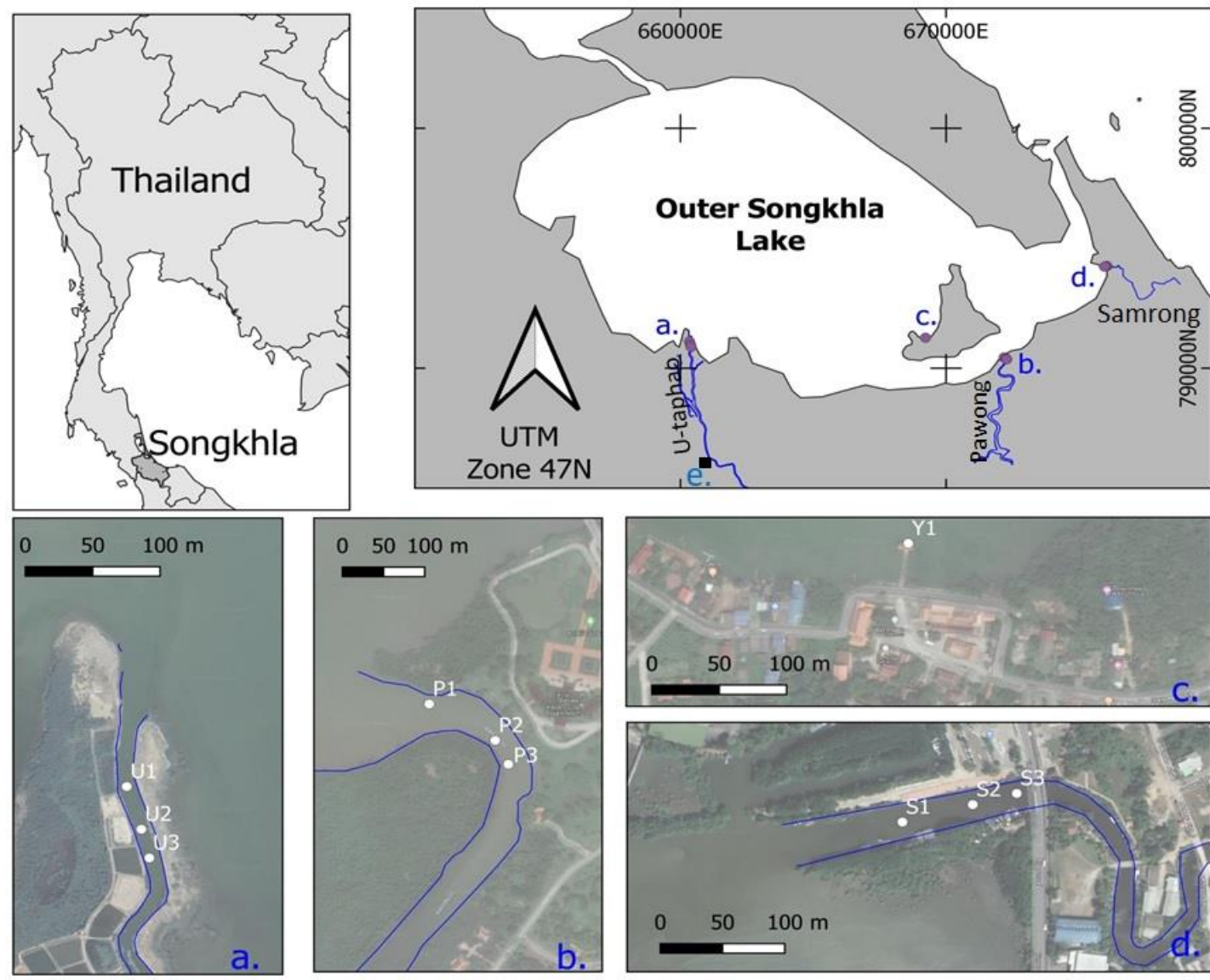

Figure 1. Sediment and water samples were collected from 3 main canals and one small island in the outer lake namely (a) U-taphao Canal, (b) Pawong Canal, (c) Ko Yoh Island, (d) Somrong Canal and (e) Local market

\section{Plastic identification}

The samples were visually observed under a microscope Olypus SZ, lens 110AL2X2 with camera Canon EOS 600D and photographed. The morphotypes of microplastic particles were classified into fiber and fragment (Li et al., 2016) and also classified into four sizes, i.e. $150-500 \mu \mathrm{m}, 500 \mu \mathrm{m}-1 \mathrm{~mm}, 1-1.5 \mathrm{~mm}$ and 1.5-5 mm (modified from Karbalaei et al., 2019). The microplastics were assessed visually (Hidalgo-Ruz et al., 2012) to describe length, color and shape (Lusher et al., 2013). Furthermore, the selected microplastic samples were analyzed to identify polymer types with a Bruker 
Lumos Fourier transform infrared (FTIR) microscope using the Attenuated Total Reflectance (ATR) mode to identify their composition. Infrared radiation in the range of $4000 \mathrm{~cm}^{-1}$ to $600 \mathrm{~cm}^{-1}$ was used. The spectra were identified by comparing with reference polymer spectra in the spectral library obtained from the samples with the Bruker spectrum library. Subsequently, several fibers of the most common ones found in the study were selected to observe microplastic surface using Field Emission Scanning Electron Microscope (FESEM), FEI, Apreo model at the Office of Scientific Instrument and Testing, Prince of Songkla University.

\section{Trace metal determination}

The same fish and shrimp samples of the microplastic analysis were randomly selected by using 6 fish of Arius maculatus, 6 shrimp of Parapenaeopsis hardwickii and 6 shrimp of Metapenaeus brevicornis in metal determination and thereafter their tissue and fish livers were dissected. All of them were dried through cold process (freeze dry), ground, sieved, kept in tightly closed polyethylene bags and stored in a desiccator for arsenic (As), cadmium $(\mathrm{Cd})$ and lead $(\mathrm{Pb})$ analyses according to AOAC Official Method (AOAC, 2005). Briefly, the analysis was initialized with the digestion of aquatic samples by weighing about $0.5 \mathrm{~g}$ of samples in a test tube, adding $2 \mathrm{ml}$ of $\mathrm{HNO}_{3}(65 \%$, Merck) and digesting in a water bath at a temperature of $95^{\circ} \mathrm{C}$ for about $1 \mathrm{~h} 30 \mathrm{~min}$. Then $0.5 \mathrm{ml} \mathrm{H}_{2} \mathrm{O}_{2}(30 \%$, Merck) was added and further digested in the temperature control water bath for about $30 \mathrm{~min}$, left to cool to room temperature and filtered through Whatman No.1 paper. The volume of the filtrate was adjusted with deionized water to get a volume of $10 \mathrm{ml}$ in volumetric flask and poured into a test tube for analyzation. Determination of trace metal $(\mathrm{As}, \mathrm{Cd}$ and $\mathrm{Pb}$ ) concentration was carried out by Inductively Coupled Plasma Optical Emission Spectrometer (ICP-OES), Perkin Elmer Optima, model 4300 DV, equipment located at Central Equipment Division, Faculty of Science, Prince of Songkla University. Additional, trace metals (As, Cd and $\mathrm{Pb}$ ) determination were applied to the sediment according to AOAC (2005).

Quality control of analysis with standard curve preparation was conducted from standard solution using Multi-Element Calibration Standard. The standard solution was diluted with deionized water to get the concentration at 0 (the value of deionized water), $0.01,0.05,0.1$, and $1 \mathrm{ppm}$. Then the standard solution and the volume adjusted filtrates of the digested aquatic samples were analyzed for arsenic, cadmium and lead concentration by measuring absorbance according to AOAC Official Method (AOAC, 2005).

\section{Data analysis}

Statistical analysis was used to calculate the minimum, maximum, average and standard deviation by Excel program. Pearson correlation test was performed to found the relationship among number of microplastic pieces found in fish stomach and trace metals in fish tissue and liver. A significance level of 0.05 was considered for all analyses.

\section{Results}

\section{Microplastics ingestion by fish and shrimp}

Overall, 172 microplastic pieces were recognized from the stomach contents of fish and shrimp (Table 2). In particular catfish (Arius macalatus) $(\mathrm{n}=11)$ with an average length of $21.02 \pm 1.17 \mathrm{~cm}$, and an average weight of $155.63 \pm 1.21 \mathrm{~g}$ contained 30 
pieces of microplastics in stomachs consisting of $90 \%$ fiber and $10 \%$ fragment with average occurrence of microplastic debris $=2.73 \pm 0.15$ pieces $/$ stomach. Spear shrimp (Parapenaeopsis hardwickii) $(\mathrm{n}=18)$ with an average length of $8.01 \pm 0.05 \mathrm{~mm}$, and an average weight of $7.45 \pm 1.18 \mathrm{~g}$ had 74 pieces of microplastics in stomachs comprising $100 \%$ fiber with average occurrence of microplastic debris $=4.11 \pm 1.12$ pieces/stomach. Yellow shrimp (Metapenaeus brevicornis) $(\mathrm{n}=18)$ had an average length of $7.16 \pm 1.15 \mathrm{~mm}$, and an average weight of $5.01 \pm 0.44 \mathrm{~g}$ and 68 pieces of microplastics in stomachs consisting of $100 \%$ fiber with average occurrence of microplastic debris $=3.78 \pm 1.12$ pieces/stomach .

Table 2. Summary of microplastics found in stomach of Arius macalatus, Parapenaeopsis hardwickii and Metapenaeus brevicornis

\begin{tabular}{c|c|c|c|c}
\hline & $\begin{array}{c}\text { A. macalatus } \\
\text { catfish } \\
(\mathbf{n = 1 1})\end{array}$ & $\begin{array}{c}\boldsymbol{P} \text {. hardwickii } \\
\text { spear shrimp } \\
(\mathbf{n}=\mathbf{1 8})\end{array}$ & $\begin{array}{c}\text { M. brevicornis } \\
\text { yellow shrimp } \\
(\mathbf{n}=\mathbf{1 8})\end{array}$ & $\begin{array}{c}\text { Total } \\
(\mathbf{n}=\mathbf{4 7})\end{array}$ \\
\hline Number of microplastics (pieces) & 30 & 74 & 68 & 172 \\
Mean number of microplastics in stomach & $2.73 \pm 0.15$ & $4.11 \pm 1.12$ & $3.78 \pm 1.12$ & $3.54 \pm 0.78$ \\
Percentage of fiber found & 90 & 100 & 100 & 96.67 \\
Percentage of fragment found & 10 & 0 & 0 & 3.33 \\
\hline
\end{tabular}

The size of the microplastics in the fish and two types of shrimp (Fig. 2) in this study were divided into 4 size intervals. In the catfish, the amount of microplastic debris found in the stomachs in both $0.5-1.0 \mathrm{~mm}$ size and $1.5-5.0 \mathrm{~mm}$ size was approximately $30 \%$, followed by the $0.15-0.5 \mathrm{~mm}$ size $(26.67 \%)$ and $1.0-1.5 \mathrm{~mm}$ size $(13.33 \%)$. For the spear shrimp (Parapenaeopsis hardwickii), the microplastic size was mostly found in $0.5-1.0 \mathrm{~mm}$ size $(33.78 \%)$, followed by $0.15-0.5 \mathrm{~mm}$ size $(25.68 \%), 1.5-5 \mathrm{~mm}$ size $(24.32 \%)$ and the least amount found in $1.0-1.5 \mathrm{~mm}$ size was $16.22 \%$. For the yellow shrimp (Metapenaeus brevicornis) the most common microplastic particles found were in $0.5-1.0 \mathrm{~mm}$ size $(44.12 \%)$, followed by both $0.15-0.5 \mathrm{~mm}$ size and $1-1.5 \mathrm{~mm}$ size $(19.12 \%)$ and the smallest amount found was in $1.5-5.0 \mathrm{~mm}$ size $(17.64 \%)$.

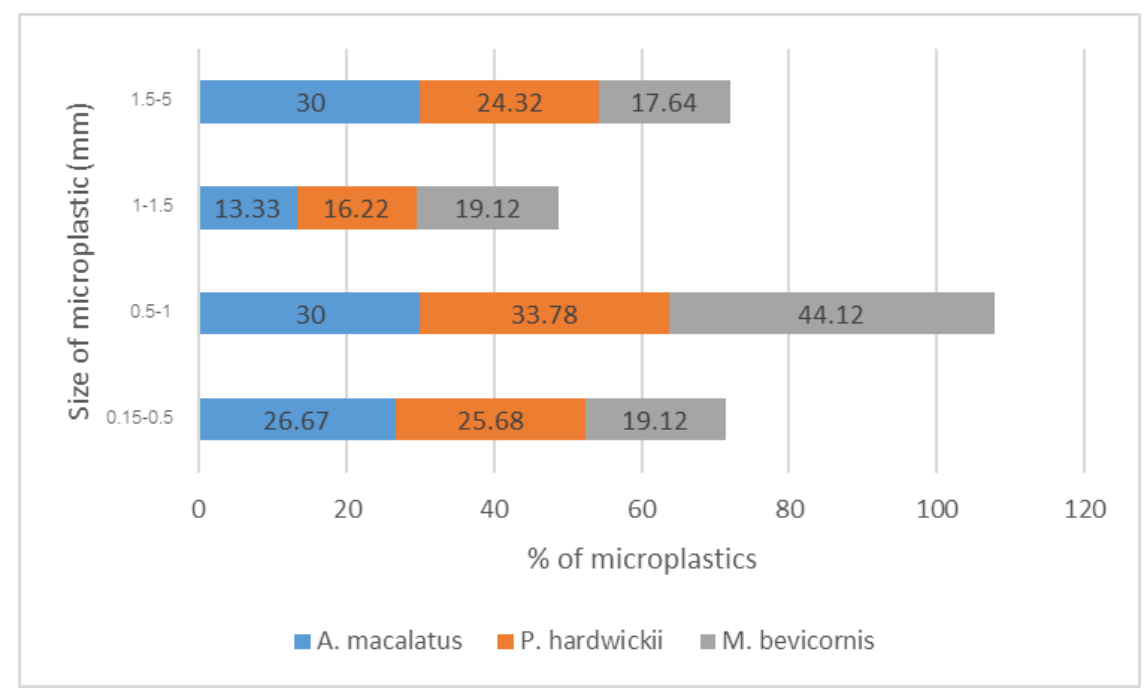

Figure 2. Size distribution of microplastics in the stomachs of fish (A. macalatus) and shrimp (P. hardwickii and M. brevicornis) 
The colors of microplastic debris present in both fish and 2 types of shrimp were found in 4 different colors which were black, blue, clear white and red. The color of the debris found was mostly black in the catfish (66\%), spear shrimp (Parapenaeopsis hardwickii) (56\%) and yellow shrimp (Metapenaeus brevicornis) (53\%), followed by blue, clear white and the least color found was red. The characteristic of microplastic debris found in fish and shrimp is shown in Figure 3. In shrimp only fiber was found whereas fish had $90 \%$ fiber and 10\% fragment.
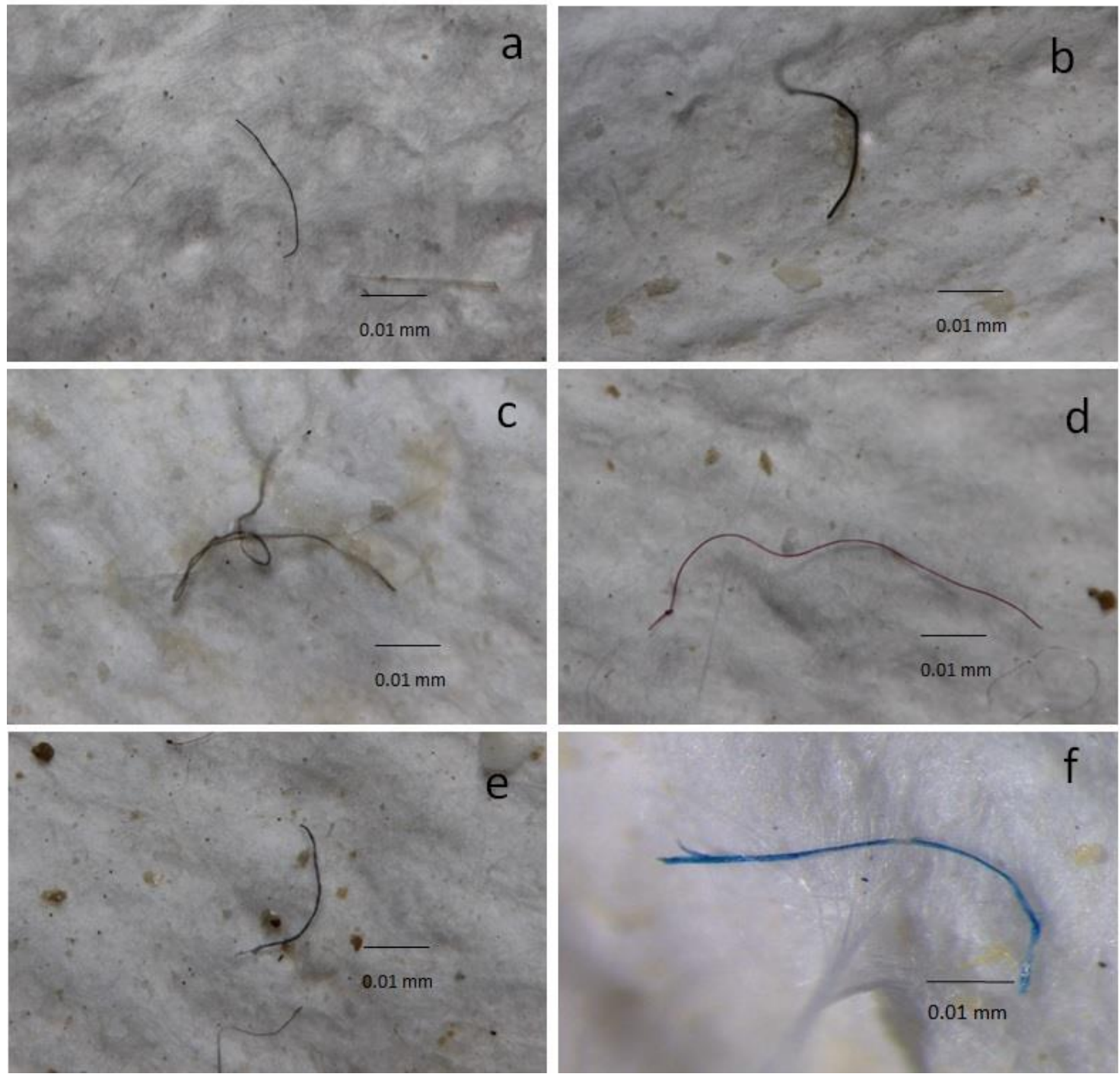

Figure 3. Selected microplastics found in the stomach contents of shrimps (a-e) and fish (f)

\section{Polymer type}

From the FTIR investigation, five types of the polymers found in this study were rayon, polyester, polyvinyl alcohol, polyethylene and paint. Among those, there were two types of specimens consisting of rayon and polyester fibers (Fig. 4) which were found in more than $50 \%$ of the samples. Thereafter rayon fibers were selected and coated with gold before investigating by Field Emission Scanning Electron Microscope (FESEM) and the fibers showed the appearance of splits and twists (Fig. 5). 

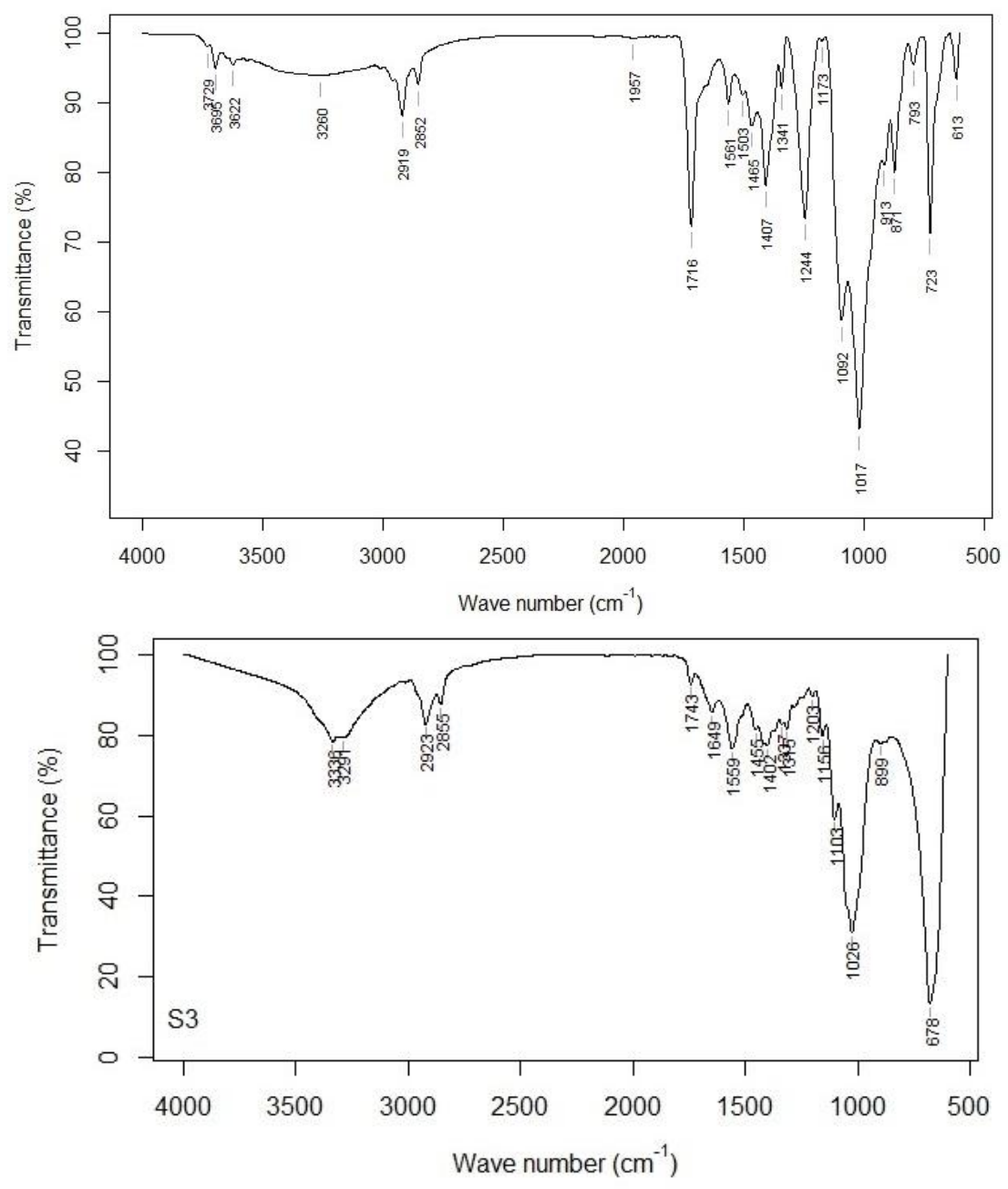

Figure 4. Top to bottom. Representatives of IR spectra of polyester (top) and rayon (bottom)

\section{Trace metal concentration in fish and shrimp tissue}

Accumulation of trace metals (As, $\mathrm{Cd}$ and $\mathrm{Pb}$ ) in fish $A$. macalatus (tissue and liver) and shrimp (tissue) was shown in Table 3 and summarized as follows; In A. macalatus, the amounts of As in tissue ranged from $<\mathrm{dl}$ to $2.73 \mathrm{mg} / \mathrm{kg}$ dry weight and $<\mathrm{dl}$ to $2.04 \mathrm{mg} / \mathrm{kg}$ dry weight of fish liver. The amounts of $\mathrm{Cd}$ ranged from $<\mathrm{dl}$ to $0.387 \mathrm{mg} / \mathrm{kg}$ dry weight of tissue and $<\mathrm{dl}-1.29$ of liver. The amounts of $\mathrm{Pb}$ ranged from < d to $1.58 \mathrm{mg} / \mathrm{g}$ dry weight of tissue and $<\mathrm{dl}-0.727 \mathrm{mg} / \mathrm{kg}$ dry weight of liver. In $P$. hardwickii, the amounts of As in tissue ranged from 1.78 to $7.28 \mathrm{mg} / \mathrm{kg}$ dry weight. $\mathrm{Cd}$ ranged from 0.064 to $0.196 \mathrm{mg} / \mathrm{g}$ dry weight of tissue and $\mathrm{Pb}$ showed nondetectable level. For M. brevicornis, the amounts of As in tissue ranged from 0.97 to $1.83 \mathrm{mg} / \mathrm{kg}$ dry weight. Cd ranged from < dl to $2.185 \mathrm{mg} / \mathrm{kg}$ and $\mathrm{Pb}$ ranged from $<\mathrm{dl}$ to $7.69 \mathrm{mg} / \mathrm{kg}$ dry weight. Overall, the amounts of As were in order of $P$. hardwickii $>A$. macalatus (tissue) $>$ A. macalatus (liver) $>M$. brevicornis for $\mathrm{Pb} M$. brevicornis $>A$. macalatus (tissue) $>A$. macalatus (liver) and $M$. brevicornis could not be detected. For $\mathrm{Cd} M$. brevicornis $>$ A. macalatus (liver). For sediment the concentrations of $\mathrm{As}, \mathrm{Pb}$ and $\mathrm{Cd}$ were 6.214-15.895 mg/g dry weight, $15.335-41.292 \mathrm{mg} / \mathrm{g}$ dry weight and 0.01$0.07 \mathrm{mg} / \mathrm{g}$ dry weight respectively. 

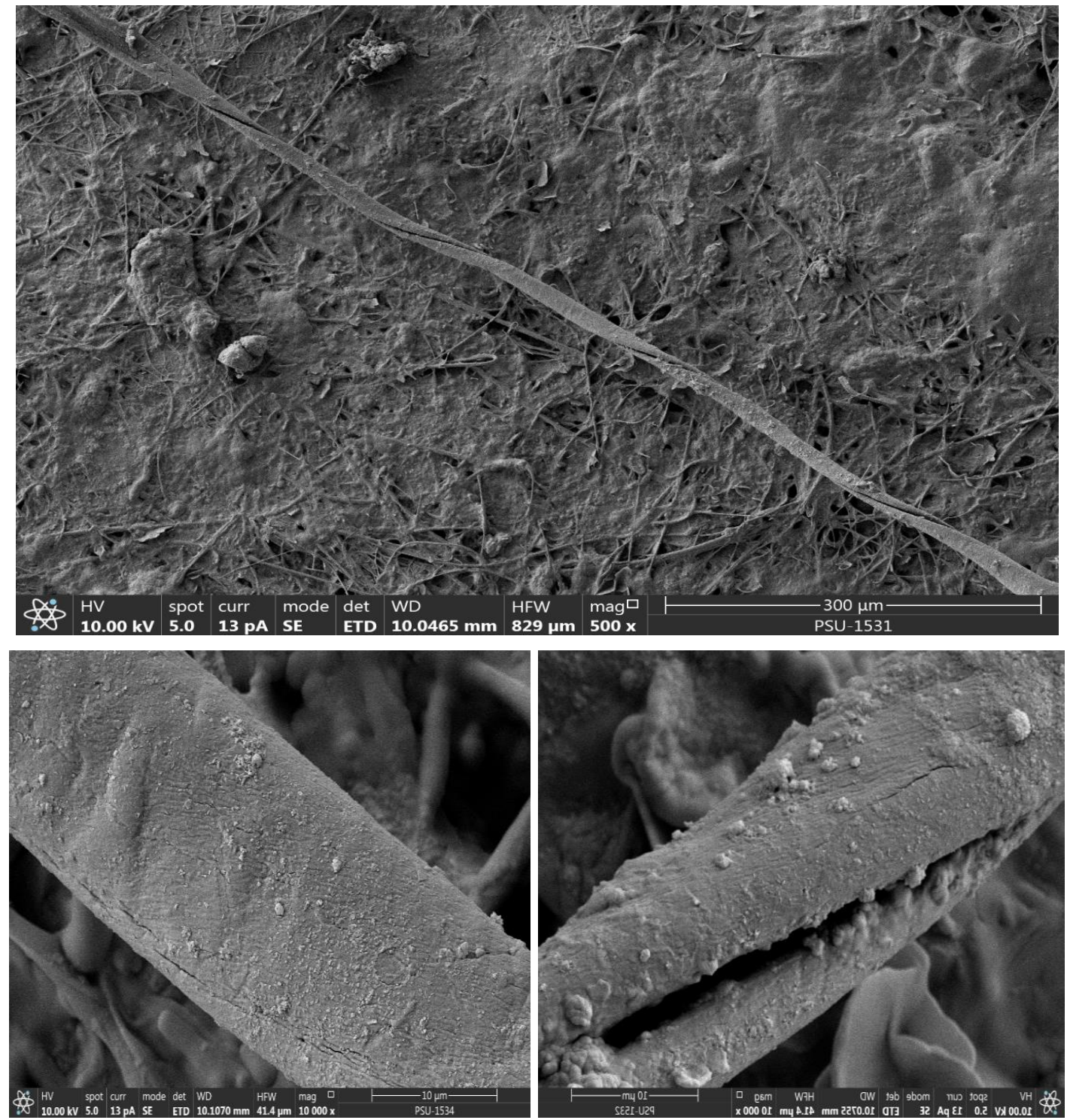

Figure 5. Top to bottom: FESEM images of the investigated microplastic appearance of rayon fibers. Twist (top), cracks (bottom)

Table 3. Concentrations of $\mathrm{As}, \mathrm{Cd}$ and $\mathrm{Pb}$ in fish and shrimp

\begin{tabular}{|c|c|c|c|c|}
\hline \multirow{2}{*}{ Common name } & \multirow{2}{*}{ Species } & \multicolumn{3}{|c|}{ Concentration (mg/kg) (dry weight) } \\
\hline & & As & $\mathrm{Cd}$ & $\mathbf{P b}$ \\
\hline Spear shrimp & P. hardwickii & $1.78-7.28$ & 0.064-0.196 & $<\mathrm{dl}$ \\
\hline Yellow shrimp & M. brevicornis & $0.97-1.83$ & $<\mathrm{dl}-2.185$ & $<\mathrm{dl}-7.69$ \\
\hline & A. macalatus (tissue) & $<\mathrm{dl}-2.73$ & $<\mathrm{dl}-0.387$ & $<\mathrm{dl}-1.58$ \\
\hline Cattish & A. macalatus (liver) & $<\mathrm{dl}-2.04$ & $<\mathrm{dl}-0.727$ & $<\mathrm{dl}-1.29$ \\
\hline
\end{tabular}

$\mathrm{dl}=$ detection limit

\section{Discussion}

This study is the first report of microplastic debris found in two marine shrimp species (P. hardwickii and M. Brevicornis) and tropical demersal fish (A. macalatus) in 
Songkhla Lake, Southern Thailand. It revealed that the majority of microplastic particles were mostly fibers which were expected to be derived from 2 main sources: 1) clothing, apparel and 2) fishing net or fixed fishing gear which decomposed into smaller debris, floated around and eventually accumulated on the sea floor and lake. Five types of the found microplastics included polyester, rayon fiber, polyvinyl alcohol, polyethylene and paint. It is very interesting that the type of microplastics found in shrimp and fish have fibers from clothing since the properties of the most commonly used fabrics made from polyester fibers are wrinkle free textile for making men's and women's clothing with easy care and durable properties. It is also popular to mix polyester fibers with other fibers, such as rayon, silk, cotton, linin, wool, etc. It is possible that during the outbreak of COVID-19 (lock down period), most people stayed at home and worked from home, which resulted in more clothes washing and a great amounts of fibers (clothing lint) caused by washing activities drained to sewers down to canals, entering the water in the lake and eventually contaminating soil and aquatic animals. There was also a possibility that the polyester fibers found would come from the washing of cloth face masks since Thai government issued a "must wear face mask" order while people left home during the outbreak of COVID-19 (March - June 2020). They mostly wore cloth face masks instead of the paper ones because they were very expensive and not available during the outbreak of COVID-19. The cloth masks are washable and needed to be washed every time people wear them. Thus, there is a chance that the fibers will be released during the washing activity. Cloth masks are mostly made from mixture of cotton and polyester. Rayon particles may originate from clothing lint from laundry. The evaluation of microplastic release caused by textile washing processes (more than 6 million microfibers of woven polyester from $5-\mathrm{kg}$ washing load) conducted by De Falco et al. (2018) clearly supported our aforementioned observation. Thus, it is about time for a new generation of washing machines with one more filter layer to remove microplastic debris of the water drained from the washing machines before releasing to the sewer since considerable microplastic debris is definitely drained to the environment each time of doing laundry by washing machines.

From the FTIR spectra in Figure 4, the spectrum shows the characteristics functional vibration of polyester (Fig. 4 top) as seen at the vibration band of carbonyl group $(\mathrm{C}=\mathrm{O})$ at $1718 \mathrm{~cm}^{-1}$ and ester group $(\mathrm{C}-\mathrm{O}-\mathrm{C})$ at $1244 \mathrm{~cm}^{-1}$ (Koto and Soegijono, 2019). Rayon (Fig. 4 bottom) is known as an artificial textile. It is made from natural resources such as wood and agricultural plants that are composed to regenerate and purify as cellulose fiber. The chemical structure of rayon is similar to cellulose chemical structure that basically has a lower molecular weight. From the rayon FTIR spectrum, the absorption band of hydroxyl group (-OH) in the cellulose structure at the wave number about $3390 \mathrm{~cm}^{-1}$ and C-H stretching at $2850-2930 \mathrm{~cm}^{-1}$ are clearly observed (Song et al., 2012). The vibration of $\mathrm{C}-\mathrm{O}-\mathrm{C}$ in the cellulose structure is observed at the wave number of $1100-1200 \mathrm{~cm}^{-1}$. Moreover, $-\mathrm{OH}$ bending from water adsorption and $\mathrm{C}-\mathrm{H}$ planar bending are shown at the adsorption peaks of $1650 \mathrm{~cm}^{-1}$ and $1390 \mathrm{~cm}^{-1}$, respectively (Auta et al., 2017).

In addition, Songkhla Lake has quite a few fishing tools including stationary fishing gears such as standing trap, set bag and moving gear such as gill net. Thus, there is a chance that the fragments of the broken fishing nets will float and accumulate in the water surface in the outer Songkhla Lake with an outlet to the lower Gulf of Thailand. The sea water from the Gulf of Thailand will flow into Songkhla Lake through the lake 
mouth during high tide and transport suspended particles including microplastics from the lake to the Gulf of Thailand during low tide. The colored fragments might come out from the broken paint from the fishing boat parking on the lake. Paint, polyester and nylon, which are common raw materials of ropes, fishing nets, fish baskets, bags and coatings used in sea may contribute to the accumulation of microplastic debris in marine organism (Thushari et al., 2017). Comparing the studies of Fang et al. (2019) on the economic fish in China, more types of polymers were found than in our studies. Their study found that the polymer types of microplastics across species could be divided into eight categories, including polypropylene (PP), polyamide (PA), polyethylene (PE), polystyrene (PS), polyethylene terephthalate (PET), polyvinyl chloride (PVC), polyacrylonitrile (PAN) and others. Potential consequences of microplastic ingestion include physical damage of the gastrointestinal track of fish and the creation of a false sensation of satiation, which could result in fish mortality from starvation (Cole et al., 2013; Nadal et al., 2016; Possatto et al., 2011). Moreover, a weakening of the olfactory senses of fish were also observed as a consequence of microplastic ingestion (Jovanović, 2017). Occurrence of plastic debris in gastrointestinal tracts of organisms could be due to trophic transfer of smaller species being prey for higher trophic organisms (Farrell and Nelson, 2013). Once microplastics enter the marine food web, they could be passed up the food chain to higher predators, including humans (Cole et al., 2011).

From the study of microplastic types in sandy soil on the beach in the lower southern part of Thailand (Kreekainut et al., 2019), there were 6 types of microplastics and polyethylene terephthalate (PET) was the most abundant, followed by polyethylene (PE), polyvinyl chloride (PVC), polypropylene (PP), polystyrene (PS) and polyamide (PA). The most common fibers with black and white colors were observed. Furthermore, from the previous study of microplastics in sediment on the beach of Libong Island, Trang Province located in the southwestern sea of Thailand by Pradit et al. (2020), there were 6 types of microplastics including polyvinyl chloride (PVC), polypropylene (PP), nylon, polyethylene (PE), polyester, polyacrylate (PA) and polymer with a structure similar to ethylene propylene diene monomer (EPDM) rubber, the microplastic colors found were white, blue and red. Surprisingly, from the aforementioned studies of both teams, no rayon fiber has been reported in the sandy areas. It is possible that rayon fibers are lightweight and drift with the currents into the open sea and eventually enter into the bodies of aquatic animals which were also reported in Azad et al. (2018) that textile fibers were found in the stomachs of fish. Currently there are no available published data on microplastics in the water of Songkhla Lake or in the seawater of the Gulf coast of the lower south of Thailand. However, the microplastic study in the coastal waters of Terenggannu State, Malaysia, which borders the southern region of Thailand conducted by Amin et al. (2020) revealed that the majority of microplastic particles found were fibers and fragments with fibers constituting a majority and the total concentration of microplastics was the greatest at station nearshore ( 9 particles/1). The increased concentrations of plastics near shore was in part, explained by the large number of fiber content, which were mostly identified as polypropylene (PP), polyethylene terephthalate (PET), polyethylene (PE), polyamide (PA) (nylon), acrylic, and polyvinyl alcohol (PVA) (Browne et al., 2011; Claessens et al., 2013; Sun et al., 2018).

The amounts of microplastic particles that accumulated in the stomachs of both fish and shrimp in this study were higher than in those study conducted by Azad et al. 
(2018) which investigated fish in the lower Gulf of Thailand in the coast of Songkhla Province. They found average occurrence of plastic particles in the pelagic fish (1.75 pieces/stomach) higher than that of demarsal fish ( 0.97 pieces/stomach $)$ by approximately two times. This was very interesting since this study found the amounts of microplastic debris accumulated in the stomatchs of fish and shrimp higher than those of the study conducted before the outbreak of COVID-19 pandemic by Azad et al. (2018) by approximately 3 times. It is possible that since this study area (Songkhla Lake) is a semi-closed area, the floating microplastic particles accumulate in the lake more than those in the open sea, and it may be the COVID-19 outbreak (lockdown period) that changed the people way of life, for example, by staying longer at home, doing more laundry, releasing more cloth fibers into sewer and lake. As compared with the study of Hossain et al. (2020), investigating microplastic contamination in two shrimp species (Tiger shrimp and Brown shrimp) in the north of the Bay of Bengal revealed that the amounts of microplastic occurrence were similar to our study. However, according to our study, only spear shrimp ( $P$. hardwickii) had more microplastic particles per stomach, which can probably be attributed to the different types of shrimp and environment between the two study sites. The shape of the microplastic particles found in both types of shrimp were $100 \%$ fibers and $90 \%$ fibers were also found in fish in which the fibers were both short pieces and coiled pieces.

In reality, fibers can naturally be folded or twisted or bundled into an aggregate. Thus, reducing their overall size and potentially increasing their bioavailability (Desforges et al., 2015). Some shrimps and fish larvae can feed on prey items which can reach lengths of up to $1.54 \mathrm{~mm}$ (Baier and Purcell, 1997). Shrimp are typically eaten without the removal of the gastrointestinal tract and thus microplastics therein could be transferred to humans via food chain (Hossain el al., 2020). Surface morphology of microplastics can change significantly through degradation in the environment caused by surface abrasion (Karbalaei et al., 2019) e.g. Figure 4 shows appearance of clear twist and crack on the surface of fiber. Inorganic and organic contaminants can absorb into pores or cracks of microplastics (Kowalski et al., 2016). However, fouling or biofouling may increase the density of these polymers (Moret-Ferguson et al., 2010; Karami, 2017) causing them to sink and become available for demersal feeders. It is interesting that Figure 4 showing photos of microplastic debris possesses cracks. These cracks probably have potential capability to accumulate trace metals or other pollutants through these crack openings and therefore over time the floating fiber fragments have the chance to be the source of trace metals or other toxic substances.

Comparing the concentration of trace metals in fish and sediment before and during the outbreak of COVID-19 in the Songkhla Lake region was conducted (Table 4). As expected, the concentrations of $\mathrm{As}, \mathrm{Cd}$ and $\mathrm{Pb}$ in the sediment before COVID-19 pandemic were slightly higher than those during COVID-19. According to sediment quality guideline such as USEPA (1989), the concentration of As classified as heavily polluted is less than $8 \mathrm{mg} / \mathrm{kg}$ dry weight whereas $\mathrm{Pb}$ values of less than $40 \mathrm{mg} / \mathrm{kg}$ dry weight during COVID-19 is classified as nonpolluted. Although the concentration of As during COVID-19 was less than that of before COVID-19 but still in a serious situation. The leakage from acid mine drainage of the tailings associated with arsenopyrite of the abandoned tin mines surrounding the Songkhla Lake Watershed is probably responsible for the high concentrations of As in sediment in the study area.

Surprisingly, no significant difference of $\mathrm{As}, \mathrm{Cd}$ and $\mathrm{Pb}$ concentrations of fish livers, fish and shrimp tissue was found between before and during the COVID-19, 
even though there was no activity of factories, companies and tourism industries performing during the 3-month lockdown and curfew measures and it was not concordant with the aforementioned chemical signature of metal concentrations of the sediment before and during COVID-19. This was probably caused by the higher retention time of the fish and shrimp exposed to the metal contaminated water during the lockdown period since less or no fishing activity was performed and therefore it provided longer time for the fish and shrimp to accumulate metals in their body before they were caught by fishermen. The longer retention time of exposing to the metal contaminated water would definitely raise the low metal concentrations of the fish and shrimp tissue to the same orders of magnitude of metal concentrations as those during COVID-19. In addition, all the factories and companies stopped working during the COVID-19 outbreak and the release of the amount of waste water, trace metals and other contaminants from their activities were expected to decrease. Thus, the amounts of metals and other pollutants present in the lake were the amounts that had been formerly accumulated.

The outer section of the lake is thus a vulnerable area regarding the mobility of As combining both important riverine inputs and reduced sediment conditions prompting mobilization of As (Pradit et al., 2010). In fish, trace metals may be concentrated at different levels in different organs of the body and may present in different forms (Pradit et al., 2010). High levels of arsenic are encountered in marine fish, but arsenic is predominantly present in nontoxic arsenobetaine form (De Gieter et al., 2002; Baeyens et al., 2009). It is worth noting that the $\mathrm{pH}$ in the water and sediment increased as expected since most of the people were detained at home and therefore, there were more clothes washing. The water from washing clothes with detergent has normally high alkaline components consisting of ions of $\mathrm{OH}^{-}, \mathrm{CO}_{3}{ }^{2-}, \mathrm{HCO}_{3}^{-}$of calcium, sodium, magnesium, potassium and ammonia. This base condition from laundry activity was certainly responsible for raising the $\mathrm{pH}$ in both water and sediment.

Table 4. Comparison of concentration of trace metal ( $\mathrm{mg} / \mathrm{g}$ dry weight) and $\mathrm{pH}$ before and during COVID-19 in Songkhla Lake

\begin{tabular}{|c|c|c|c|c|c|c|c|}
\hline Situation & Species & As & Cd & $\mathbf{P b}$ & pHsed & pHwat & Reference \\
\hline \multirow{8}{*}{$\begin{array}{c}\text { Before } \\
\text { COVID }\end{array}$} & A macalatus $(\mathrm{T})$ & $1.86-7.25$ & $<\mathrm{dl}-0.37$ & $0.06-0.19$ & & \multirow{8}{*}{$\begin{array}{c}7.00-8.20 \\
- \\
- \\
7.03-7.85 \\
7.07-9.49\end{array}$} & Pradit et al., 2010 \\
\hline & A macalatus (L) & $1.35-1.96$ & $0.039-0.47$ & $0.75-1.80$ & & & Pradit et al., 2010 \\
\hline & Sediment & $0.8-70.7$ & $0.1-2.4$ & $8.2-13.1$ & & & Pradit et al., 2010 \\
\hline & Sediment & $7.0-30.0$ & $0.14-0.92$ & $19.0-66.0$ & $7.00-7.50$ & & Pradit et al., 2013 \\
\hline & Sediment & $11.33-15.11$ & - & $11.99-14.03$ & $7.00-7.50$ & & Aunjangwang,2014 \\
\hline & Sediment & $18.55-24.41$ & - & $38.35-59.35$ & $6.78-7.21$ & & Baruddin, 2017 \\
\hline & Sediment & $20.35-50.50$ & $0.01-0.18$ & $48.8-78.8$ & $6.71-7.53$ & & Pradit et al., 2018 \\
\hline & Sediment & $14.90-58.10$ & $0.07-0.11$ & $38.9-79.7$ & $6.71-9.00$ & & Pradit et al., 2019 \\
\hline \multirow{5}{*}{$\begin{array}{l}\text { During } \\
\text { COVID }\end{array}$} & A. macalatus $(\mathrm{T})$ & $<\mathrm{dl}-2.73$ & $<\mathrm{dl}-0.39$ & $<\mathrm{dl}-1.58$ & \multirow[b]{5}{*}{$8.04-8.76$} & \multirow[b]{5}{*}{$7.89-8.72$} & This study \\
\hline & A. macalatus $(\mathrm{L})$ & $<\mathrm{dl}-2.04$ & $<\mathrm{dl}-0.73$ & $<\mathrm{dl}-1.29$ & & & This study \\
\hline & P. hardwickii & $1.78-7.28$ & $0.06-0.20$ & $<\mathrm{dl}$ & & & This study \\
\hline & M. brevicornis & $0.97-1.83$ & $<\mathrm{dl}-2.19$ & $<\mathrm{dl}-7.69$ & & & This study \\
\hline & Sediment & $6.21-15.90$ & $0.01-0.07$ & $15.34-41.29$ & & & This study \\
\hline
\end{tabular}

$\mathrm{T}=$ tissue, $\mathrm{L}=$ liver, $\mathrm{dl}=$ detection limit, sed $=$ sediment, wat $=$ water

From the previous studies, it was well known that microplastic particles have a potential to absorb the cations such as metal ions and persistent organic pollutants (POPs) 
dissolved in water and thus, they can act like contaminant scavengers and carriers certainly posing a hazardous risk on aquatic animals, food webs and food security. Hence, the more microplastic pieces are present in the stomachs or gastrointestinal tracts of aquatic animals, the higher metal concentrations in animal tissue are. Surprisingly, from determining the correlation coefficient between numbers of microplastic particles found in fish stomachs and trace metal concentrations in fish fillets and their livers revealed that the numbers of microplastic particles had negative correlation coefficients with all the metal concentrations in fish tissue and liver $(\mathrm{r}=-0.904,-0.469,-0.415$ and -0.373$)$ ( $\mathrm{p}<0.05)$ except As (Table 5). A similar trend was also observed in spear shrimp. However, fairly low positive correlation coefficients between the numbers of microplastic particles and metal concentrations were observed in yellow shrimp. This chemical signature was probably caused by the microplastic debris present in fish and shrimp in our study possessing less or no ability of absorbing trace metal ions. This is not congruent with most previous studies. The possible explanation for this anomalous finding was that the microplastics present in the stomachs of fish and shrimp in our study were probably new born microplastic particles and therefore, had very little or no ability of metal absorbing metal ions. Over time, there were biofouling accumulation on these microplastic pieces resulting in increasing their metal absorbing ability. Thus, the metal absorbing ability of microplastic debris increases with age (Fig. 6). Furthermore, the study of biofouling is a source of metal pollution conducted by Bighiu et al. (2017) supporting our aforementioned explanation. Hence, normally the moderate or high positive correlation coefficients between the numbers of mature and old microplastic particles and metal concentrations were mostly found in the previous studies whereas the fairly low positive to negative correlation coefficients were observed in the new or young microplastic debris of our study.

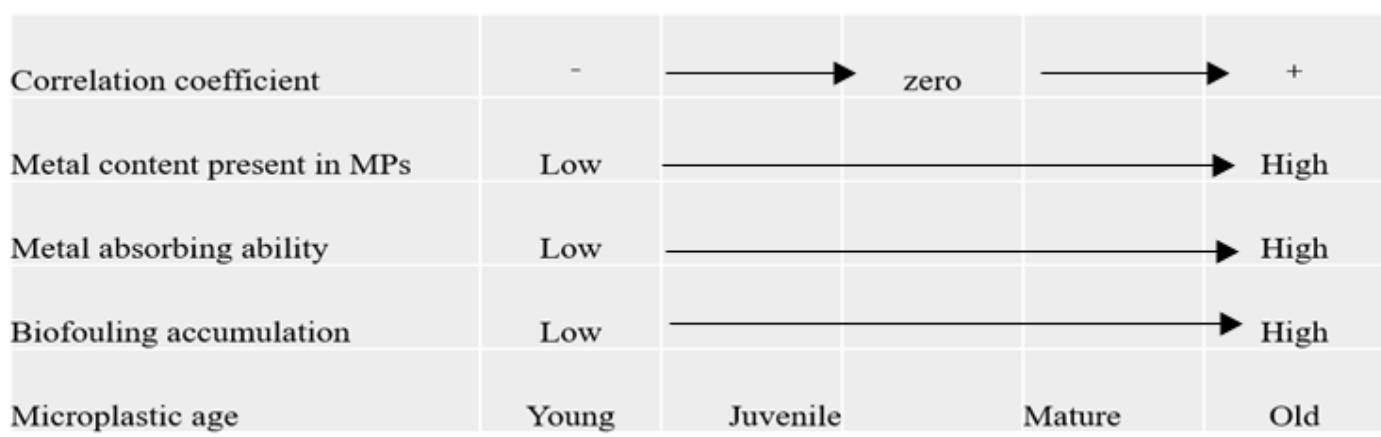

Figure 6. Diagram of chemical property of microplastic change with time

From calculating numbers of microplastic pieces per gram of body wet weight in this study (Table 6), it was found that $M$. brevicornis shrimp had microplastic occurrence of $0.76 \pm 0.48$ pieces/g (wet weight) and $P$. hardwickii shrimp possessed $0.55 \pm 1.19$ pieces $/ g$ (wet weight). This was well agreed with the study in brown shrimp, Crangon crangon, a commercially important crustacean in the eastern Atlantic and Mediterranean Sea, microplastic were found an average of $0.68 \pm 0.55$ pieces $/ g$ (wet weight) (Devriese et al., 2015). For the fish (A. macalatus) in this study, the amount of microplastic pieces found was $0.018 \pm 0.27$ pieces $/ g$ (wet weight), which was less than that of shrimp and fish from other areas. For example, as compared to that in Scomber japonicus (Güven et al., 2017) it was estimated at approximately 0.33 pieces/g (wet weight), in Engraulis ringens it was 
0.057 pieces/g (wet weight). However, when compared to mussels (Goh et al., 2019), both shrimp and fish from this study, the microplastic pieces found were much less amounts. Factors influencing microplastic consumption are feeding strategy and environmental prevalence that are primary drivers for microplastic consumption. Generally, lower trophic level organisms appear to ingest more microplastics due to feeding strategy (Walkinshaw et al., 2020). Calculating the weight of microplastic pieces found in fish and shrimp in our study using the consumption rate of meat, fish or seafood of $85 \mathrm{~g} /$ person/day (Puangsuwan, 2014) it was found that there was an opportunity for Thai consumers to get microplastic pieces from shrimp and fish consumption between 1.53-64.6 pieces/day. Hence, this means that microplastic contamination currently occurs in brackish water food chain and jeopardizes Thai food security since Songkhla Lake is the biggest lake of Thailand and one of the most significant food sources of the people in lower south of Thailand.

Recently, the information on health risks through the intake of trace metals has been led to a potential interest of the consumers (Barone et al., 2015). Trace metals like As (inorganic) have long time exposure that leads to the occurrence of skin, vascular, nervous system disorders, birth defects, reproductive problems, and finally, people with prolonged exposure to As tend to develop some form of cancer (Bosch et al., 2016). Cd may be a carcinogen and $\mathrm{Pb}$ can damage blood circulation (Rahman et al., 2012; Arnich et al., 2012).

Table 5. Correlation coefficients $(R)$ at $p<0.05$ between number of microplastic (MPs) found in fish stomachs and trace metals ( $\mathrm{mg} / \mathrm{kg}$ dry weight) in (a) catfish tissue and liver, (b) spear shrimp and (c) yellow shrimp

\begin{tabular}{c|c|c|c|c|c|c|c|c|c}
\hline (a) Catfish & MPs & Weight & Length & As_T & Cd_T & Pb_T & As_L & Cd_L & Pb_L \\
\hline MPs & 1 & & & & & & & & \\
weight & 0.498 & 1 & & & & & & & \\
length & 0.427 & $\mathbf{0 . 9 8 2}$ & 1 & & & & & & \\
As_T & 0.494 & -0.173 & -0.181 & 1 & & & & & \\
Cd_T & -0.373 & 0.022 & 0.043 & $\mathbf{- 0 . 9 2 1}$ & 1 & & & & \\
Pb_T & -0.415 & 0.015 & 0.026 & $\mathbf{- 0 . 9 4 7}$ & $\mathbf{0 . 9 9 5}$ & 1 & & & \\
As_L & 0.513 & 0.595 & 0.472 & 0.081 & -0.309 & -0.265 & 1 & & \\
Cd_L & $\mathbf{- 0 . 9 0 4}$ & -0.735 & -0.687 & -0.248 & 0.232 & 0.266 & -0.680 & 1 & \\
Pb_L & -0.469 & -0.254 & -0.220 & -0.284 & 0.379 & 0.375 & -0.724 & 0.650 & 1 \\
\hline
\end{tabular}

\begin{tabular}{c|c|c|c|c|c}
\hline (b) Spear shrimp & MPs & weight & length & As & Cd \\
\hline MPs & 1 & & & & \\
weight & 0.631 & 1 & & & \\
length & $\mathbf{0 . 8 6 2}$ & 0.508 & 1 & & \\
As & -0.167 & -0.214 & 0.312 & 1 & \\
Cd & -0.223 & -0.269 & 0.286 & $\mathbf{0 . 9 8 1}$ & 1 \\
\hline
\end{tabular}

\begin{tabular}{c|c|c|c|c|c}
\hline (c) Yellow shrimp & MPs & weight & length & As & Cd \\
\hline MPs & 1 & & & & \\
weight & -0.179 & 1 & & & \\
length & 0.029 & $\mathbf{0 . 8 2 1}$ & 1 & & \\
As & 0.638 & -0.385 & -0.352 & 1 & \\
Cd & 0.314 & -0.031 & -0.413 & 0.211 & 1 \\
\hline
\end{tabular}

Significant results are highlighted. MPs $=$ microplastics, $\mathrm{T}=$ tissue, $\mathrm{L}=$ liver 
Table 6. Numbers of microplastic pieces per gram of body wet weight of marine organisms

\begin{tabular}{c|c|c|c}
\hline Species & Common name & Number of microplastic & References \\
\hline P. hardwickii & Spear shrimp & $0.55 \pm 1.19$ & This study \\
M. brevicornis & Yellow shrimp & $0.76 \pm 0.48$ & This study \\
A. macalatus & Catfish & $0.018 \pm 0.27$ & This study \\
Scomber japonicus & Fish & 0.33 & Güven et al., 2017 \\
Engraulis ringens & Peruvian anchovy & 0.057 & Ory et al., 2018 \\
Perna viridis & Green mussel & $21.10 \pm 0.15$ & Goh et al., 2019 \\
Crangon crangon & Brown shrimp & $0.68 \pm 0.55$ & Devriese et al., 2015 \\
\hline
\end{tabular}

\section{Conclusion}

The main content of this study was to investigate gastric microplastic and trace metal content $(\mathrm{As}, \mathrm{Cd}$ and $\mathrm{Pb})$ in tissues of the dominant aquatic organisms in outer Songkhla Lake, which were the catfish and two shrimps, that microplastic pieces were found. The accumulated fiber types and their polymer types were derived from the main component of clothing and fishing gear. During the study period, the COVID-19 outbreak with the government lockdown order, there was no inter-provincial travel and no activity of both private and government organizations for approximately 3 months. Thus, this certainly changed the people's lifestyle by staying at home and working from home, resulting in more laundry activities, releasing more cloth fibers into the drain water and finally entering the Songkhla Lake. Thus, it is recommended that new generation of washing machines should be installed with one more filter layer to get rid of microplastic debris in drain water from the washing machines before releasing to sewer since substantial microplastic debris is definitely drained to the environment each time of doing laundry by washing machines. From most of the previous studies, normally the numbers of microplastic particles present in the stomachs of aquatic organisms should have moderate to high positive correlation coefficients with most of the metal concentrations in their tissues. In fact, this study showed the negative correlation coefficients with all the metal concentrations in fish tissue and liver except for As. A similar trend was also observed in spear shrimp but fairly low positive correlation coefficients between the numbers of microplastic particles and metal concentrations were observed in yellow shrimp. This anomalous chemical signature was probably caused by the microplastics present in the stomachs of fish and shrimp in our study were probably new born microplastic particles and therefore, had very little or no ability of absorbing metal ions. Over time, there was biofouling accumulation on these microplastic pieces resulting in increasing their metal absorbing ability. Thus, the metal absorbing ability of microplastic debris increases with age. Normally the moderate or high positive correlation coefficients between the numbers of mature and old microplastic particles and metal concentrations in organisms were mostly found in the previous studies whereas the fairly low positive to negative correlation coefficients were observed in the new or young microplastic debris of this study. However, there should be studies to monitor the amounts of microplastic pieces in other aquatic animals additionally, since they probably pose potential harmful effects on the health of aquatic organisms, ecosystems and humans.

Acknowledgements. This paper was fully supported by Faculty of Environmental Management Research Fund 2020 (code ENV6304125c), Prince of Songkla University. We thank the anonymous reviewers for their careful reading of our manuscript and their comments. 


\section{REFERENCES}

[1] Amin, M. R., Sohaimi, E. S., Anuar, S. T., Bachok, Z. (2020): Microplastic ingestion by zooplankton in Terengganu coastal waters, southern South China Sea. - Marine Pollution Bulletin 150: 110616.

[2] Andrady, A. L. (2011): Microplastics in the marine environment. - Marine Pollution Bulletin 62: 1596-1605.

[3] Angsupanich, S., Somsak, S., Phrommoon, J. (2005): Stomach contents of the catfishes Osteogeneiosus militaris (Linnaeus, 1758) and Arius maculatus (Thunberg, 1792) in the Songkhla Lake. - Songklanakarin Journal of Science and Technology 27: 391-402.

[4] AOAC (2005): Official Methods of Analysis of AOAC International. 18th Ed. - In: Horwitz, W., Latimer, G. W. (eds.) Metals and Other Elements. AOAC, Gaithersburg, Maryland.

[5] Arnich, N., Sirot, V., Rivière, G., Jean, J., Noël, L., Guérin, T., Leblanc, J.-C. (2012): Dietary exposure to trace elements and health risk assessment in the 2nd French Total Diet Study. - Food and Chemical Toxicology 50: 2432-2449.

[6] Aunjangwang, N. (2014): Contamination of arsenic and lead in sediment of U-Taphao Canal. - PhD thesis, Prince of Songkla University, Songkla.

[7] Auta, R., Adamus, G., Kwiecien, M., Radecka, I., Hooley, P. (2017): Production and characterization of bacterial cellulose before and after enzymatic hydrolysis. - Journal of Biotechnology 16: 470-482.

[8] Azad, S. M. O., Towatana, P., Pradit, S., Goh, P. B., Hue, H. T. T., Jualaong, S. (2018): First evidence of existence of microplastics in stomach of some commercial fishes in the lower Gulf of Thailand. - Applied Ecology and Environmental Research 16: 7345-7360.

[9] Baeyens, W., Gao, Y., Galan, S. De, Bilau, M., Larebeke, N. Van, Leermakers, M. (2009): Dietary exposure to total and toxic arsenic in Belgium: importance of arsenic speciation in North Sea fish. - Molecular Nutrition \& Food Research 53: 558-565.

[10] Baier, C., Purcell, J. (1997): Trophic interactions of chaetognaths, larval fish, and zooplankton in the South Atlantic Bight. - Marine Ecology Progress Series 146: 43-53.

[11] Barone, G., Storelli, A., Garofalo, R., Busco, V. P., Quaglia, N. C., Centrone, G., Storelli, M. M. (2015): Assessment of mercury and cadmium via seafood consumption in Italy: estimated dietary intake (EWI) and target hazard quotient (THQ). - Food Additives \& Contaminants Part A 32: 1277-1286.

[12] Baruddin, N. A., Shazili, N. A. M., Pradit, S. (2017): Sequential extraction analysis of heavy metals in relation to bioaccumulation in mangrove, Rhizophora mucronata from Kelantan Delta, Malaysia. - AACL Bioflux 10: 172-181.

[13] Bighiu, M. A., Eriksson-Wiklund, A. K., Eklund, B. (2010): Biofouling of leisure boats as a source of metal pollution. - Environ Sci Pollut Res 24: 997-1006-

[14] Bosch, A. C., O’Neill, B., Sigge, G. O., Kerwath, S. E., Hoffman, L. C. (2016): Heavy metals in marine fish meat and consumer health: a review. - Journal of the Science of Food and Agriculture 96: 32-48.

[15] Browne, M. A., Crump, P., Niven, S. J., Teuten, E., Tonkin, A., Galloway, T., Thompson, R. (2011): Accumulation of microplastic on shorelines worldwide: sources and sinks. - Environmental Science \& Technology 45: 9175-9179.

[16] Claessens, M., Cauwenberghe, L. Van, Vandegehuchte, M. B., Janssen, C. R. (2013): New techniques for the detection of microplastics in sediments and field collected organisms. - Marine Pollution Bulletin 70: 227-233. 
[17] Cole, M., Lindeque, P., Fileman, E., Halsband, C., Goodhead, R., Moger, J., Galloway, T. S. (2013): Microplastic ingestion by zooplankton. - Environmental Science \& Technology 47: 6646-6655.

[18] Cole, M., Lindeque, P., Halsband, C., Galloway, T. S. (2011): Microplastics as contaminants in the marine environment: a review. - Marine Pollution Bulletin 62: 25882597.

[19] Cole, M., Webb, H., Lindeque, P. K., Fileman, E. S., Halsband, C., Galloway, T. S. (2014): Isolation of microplastics in biota-rich seawater samples and marine organisms. Scientific Reports 4: 4528.

[20] De Falco, F., Gullo, M. P., Gentile, G., Di Pace, E., Cocca, M., Gelabert, L., BroutaAgnesa, M., Rovira, A., Escudero, R., Villalba, R., Mossotti, R., Montarsolo, A., Gavignano, S., Tonin, C., Avella, M. (2018): Evaluation of microplastic release cause by textile washing processes of synthetic fabrics. - Environ Pollut 236: 916-925.

[21] De Gieter, M., Leermakers, M., Ryssen, R. Van, Noyen, J., Goeyens, L., Baeyens, W. (2002): Total and toxic arsenic levels in North Sea fish. - Archives of Environmental Contamination and Toxicology 43: 406-417.

[22] De Witte, B., Devriese, L., Bekaet, K., Hoffman, S., Vandermeersch, G., Cooreman, K. (2004): Quality assessment of the blue mussel (Mytilus edulis): comparison between commercial and wild types. - Mar. Pollut. Bull. 85(1): 146-155.

[23] Desforges, J.-P. W., Galbraith, M., Ross, P. S. (2015): Ingestion of microplastics by zooplankton in the Northeast Pacific Ocean. - Archives of Environmental Contamination and Toxicology 69: 320-330.

[24] Devriese, L. I., Meulen, M. D. van der, Maes, T., Bekaert, K., Paul-Pont, I., Frère, L., Robbens, J., Vethaak, A. D. (2015): Microplastic contamination in brown shrimp (Crangon crangon, Linnaeus 1758) from coastal waters of the Southern North Sea and Channel area. - Marine Pollution Bulletin 98: 179-187.

[25] Ding, J.-F., Li, J.-X., Sun, C.-J., He, C.-F., Jiang, F.-H., Gao, F.-L., Zheng, L. (2018): Separation and identification of microplastics in digestive system of bivalves. - Chinese Journal of Analytical Chemistry 46: 690-697.

[26] Eriksen, M., Lebreton, L. C. M., Carson, H. S., Thiel, M., Moore, C. J., Borerro, J. C., Galgani, F., Ryan, P. G., Reisser, J. (2014): Plastic pollution in the world's oceans: more than 5 trillion plastic pieces weighing over 250,000 tons afloat at sea. - PLoS ONE 9: e111913.

[27] Fang, C., Zheng, R., Chen, H., Hong, F., Lin, L., Lin, H., Guo, H., Bailey, C., Segner, H., $\mathrm{Mu}$, J., Bo, J. (2019): Comparison of microplastic contamination in fish and bivalves from two major cities in Fujian province, China and the implications for human health. Aquaculture 512: 734322.

[28] Farrell, P., Nelson, K. (2013): Trophic level transfer of microplastic: Mytilus edulis (L.) to Carcinus maenas (L.). - Environmental Pollution 177: 1-3.

[29] GESAMP (2015): Sources, Fate and Effects of Microplastics in the Marine Environment: A Global Assessment. - GESAMP, London.

[30] Gilman, E. (2015): Status of international monitoring and management of abandoned, lost and discarded fishing gear and ghost fishing. - Marine Policy 60: 225-239.

[31] Goh, P., Pradit, S., Towatana, P., Khokkiatiwong, S., Azad, S. (2019): Microplastics in green mussel Perna viridis from Singhanakorn District, Songkhla Province, Thailand. Proceedings of the 34th AUAP Annual Conference 2019 Climate Change Adaptation. The Challenging Role of Higher Education Institutions, pp. 19-23. 
[32] Gordon, M. (2006): Eliminating Land-Based Discharges of Marine Debris in California: A Plan of Action from the Plastic Debris Project. - California Coastal Commission, California.

[33] Güven, O., Gökdağ, K., Jovanović, B., Kıdeyş, A. E. (2017): Microplastic litter composition of the Turkish territorial waters of the Mediterranean Sea, and its occurrence in the gastrointestinal tract of fish. - Environmental Pollution 223: 286-294.

[34] Hidalgo-Ruz, V., Gutow, L., Thompson, R. C., Thiel, M. (2012): Microplastics in the marine environment: a review of the methods used for identification and quantification. Environmental Science \& Technology 46: 3060-3075.

[35] Hossain, M. S., Rahman, M. S., Uddin, M. N., Sharifuzzaman, S. M., Chowdhury, S. R., Sarker, S., Nawaz Chowdhury, M. S. (2020): Microplastic contamination in Penaeid shrimp from the Northern Bay of Bengal. - Chemosphere 238: 124688.

[36] Hutchings, J. A., Reynolds, J. D. (2004): Marine fish population collapse: consequences for recovery and extinction risk. - Bioscience 54: 297-309.

[37] Jabeen, K., Su, L., Li, J., Yang, D., Tong, C., Mu, J., Shi, H. (2017): Microplastics and mesoplastics in fish from coastal and fresh waters of China. - Environmental Pollution 221: 141-149.

[38] Jovanović, B. (2017): Ingestion of microplastics by fish and its potential consequences from a physical perspective. - Integrated Environmental Assessment and Management 13: 510-515.

[39] Karami, A. (2017): Gaps in aquatic toxicological studies of microplastics. Chemosphere 184: 841-848.

[40] Karbalaei, S., Golieskardi, A., Hamzah, H. B., Abdulwahid, S., Hanachi, P., Walker, T. R., Karami, A. (2019): Abundance and characteristics of microplastics in commercial marine fish from Malaysia. - Marine Pollution Bulletin 148: 5-15.

[41] Koto, N., Soegijono, B. (2019): Effect of rice husk ash filler of resistance against of high-speed projectile impact on polyester-fiberglass double panel composites. - Journal of Physics Conference Series 1191: 012058.

[42] Kowalski, N., Reichardt, A. M., Waniek, J. J. (2016): Sinking rates of microplastics and potential implications of their alteration by physical, biological, and chemical factors. Marine Pollution Bulletin 109: 310-319.

[43] Kreekrinut, T., Puttapreecha, R., Suksuwan, R., Tangjai, R., Saisahat, R. (2019): The contamination of microplatics in Sediment beach area, Lower Gulf of Thailand. https://dmcr.go.th/detailLib/4536.

[44] Kripa, V., Nair, P. G., Dhanya, A. M., Pravitha, V. P., Abhilash, K. S., Mohammed, A. A., Vijayan, D., Vishnu, P. G., Mohan, G., Anil Kumar, P. S., Khambadker, L. R., Prema, D. (2014): Microplastics in the gut of anchovies caught from the mud bank area of Alappuzha, Kerala. - Mar. Fish. Inf. Serv. Tech. Ext. Ser. 219: 27-28.

[45] Li, J., Qu, X., Su, L., Zhang, W., Yang, D., Kolandhasamy, P., Li, D., Shi, H. (2016): Microplastics in mussels along the coastal waters of China. - Environmental Pollution 214: 177-184.

[46] Lu, Y., Zhang, Y., Deng, Y., Jiang, W., Zhao, Y., Geng, J., Ding, L., Ren, H. (2016): Uptake and accumulation of polystyrene microplastics in zebrafish (Danio rerio) and toxic effects in liver. - Environmental Science \& Technology 50: 4054-4060.

[47] Lusher, A. L., McHugh, M., Thompson, R. C. (2013): Occurrence of microplastics in the gastrointestinal tract of pelagic and demersal fish from the English Channel. - Marine Pollution Bulletin 67: 94-99. 
[48] Morét-Ferguson, S., Law, K. L., Proskurowski, G., Murphy, E. K., Peacock, E. E., Reddy, C. M. (2010): The size, mass, and composition of plastic debris in the western North Atlantic Ocean. - Marine Pollution Bulletin 60: 1873-1878.

[49] Nadal, M. A., Alomar, C., Deudero, S. (2016): High levels of microplastic ingestion by the semipelagic fish bogue Boops boops (L.) around the Balearic Islands. Environmental Pollution 214: 517-523.

[50] Ory, N. C., Sobral, P., Ferreira, J. L., Thiel, M. (2017): Amberstripe scad Decapterus muroadsi (Carangidae) fish ingest blue microplastics resembling their copepod prey along the coast of Rapa Nui (Easter Island) in the South Pacific subtropical gyre. Science of The Total Environment 586: 430-437.

[51] Possatto, F. E., Barletta, M., Costa, M. F., Ivar do Sul, J. A., Dantas, D. V. (2011): Plastic debris ingestion by marine catfish: an unexpected fisheries impact. - Marine Pollution Bulletin 62: 1098-1102.

[52] Pozo, K., Gomez, V., Torres, M., Vera, L., Nuñez, D., Oyarzún, P., Mendoza, G., Clarke, B., Fossi, M. C., Baini, M., Přibylová, P., Klánová, J. (2019): Presence and characterization of microplastics in fish of commercial importance from the Biobío region in central Chile. - Marine Pollution Bulletin 140: 315-319.

[53] Pradit, S., Wattayakorn, G., Angsupanich, S., Baeyens, W., Leermakers, M. (2010): Distribution of trace elements in sediments and biota of Songkhla Lake, Southern Thailand. - Water, Air, and Soil Pollution 206: 155-174.

[54] Pradit, S., Gao, Y., Faiboon, A., Galan, S. De, Baeyens, W., Leermakers, M. (2013): Application of DET (diffusive equilibrium in thin films) and DGT (diffusive gradients in thin films) techniques in the study of the mobility of sediment-bound metals in the outer section of Songkhla Lake, Southern Thailand. - Environmental Monitoring and Assessment 185: 4207-4220.

[55] Pradit, S., Shazili, N. A. M., Pattaratumrong, M. S., Chotikarn, P., Kobkeatthawin, T., Yucharoen, M., Towatana, P. (2018): Accumulation of trace metals in mangrove plant Soneratia Caseoralis in Songkhla Lake, Thailand. - Applied Ecology and Environmental Research 16(4): 4081-4095.

[56] Pradit, S., Mohamed Shazili, N. A., Pattaratumrong, M. S., Chotikarn, P., Yucharoen, M., Towatana, P. (2019): Chemical fractionation of trace elements in mangrove sediments from the Songkhla Lake, Thailand using BCR technique. - ScienceAsia 45: 465.

[57] Pradit, S., Towatana, P., Nitiratsuwan, T., Jualaong, S., Jirajarus, M., Sornplang, K., Noppradit, P., Darakai, Y., Weerawong, C. (2020): Occurrence of microplastics on beach sediment at Libong, a pristine island in Andaman Sea, Thailand. - ScienceAsia 46: 336.

[58] Puangsuwan, S. (2014): Heavy metal concentration in tuna from Ninety East Ridge. Master thesis, Prince of Songkla University, Songkhla.

[59] Rahman, M. S., Molla, A. H., Saha, N., Rahman, A. (2012): Study on heavy metals levels and its risk assessment in some edible fishes from Bangshi River, Savar, Dhaka, Bangladesh. - Food Chemistry 134: 1847-1854.

[60] Rainbow, P. S. (2002): Trace metal concentrations in aquatic invertebrates: why and so what? - Environmental Pollution 120: 497-507.

[61] Rocha-Santos, T., Duarte, A. C. (2015): A critical overview of the analytical approaches to the occurrence, the fate and the behavior of microplastics in the environment. - TrAC Trends in Analytical Chemistry 65: 47-53.

[62] Setälä, O., Fleming-Lehtinen, V., Lehtiniemi, M. (2014): Ingestion and transfer of microplastics in the planktonic food web. - Environmental Pollution 185: 77-83. 
[63] Sivan, A. (2011): New perspectives in plastic biodegradation. - Current Opinion in Biotechnology 22: 422-426.

[64] Song, J., Birbach, N. L., Hinestroza, J. P. (2012): Deposition of silver nanoparticles on cellulosic fibers via stabilization of carboxymethyl groups. - Cellulose 19: 411-424.

[65] Sun, X., Liang, J., Zhu, M., Zhao, Y., Zhang, B. (2018): Microplastics in seawater and zooplankton from the Yellow Sea. - Environmental Pollution 242: 585-595.

[66] Thushari, G. G. N., Senevirathna, J. D. M., Yakupitiyage, A., Chavanich, S. (2017): Effects of microplastics on sessile invertebrates in the eastern coast of Thailand: an approach to coastal zone conservation. - Marine Pollution Bulletin 124: 349-355.

[67] US EPA (1989): Assessing Human Health Risks from Chemically Contaminated Fish and Shellfish. A Guidance Manual. - EPA-503/8-89-002. EPA, Washington, DC.

[68] Van Cauwenberghe, L., Janssen, C. R. (2014): Microplastics in bivalves cultured for human consumption. - Environ. Pollut. 193: 65-70.

[69] Walkinshaw, C., Lindeque, P. K., Thompson, R., Tolhurst, T., Cole, M. (2020): Microplastics and seafood: lower trophic organisms at highest risk of contamination. Ecotoxicology and Environmental Safety 190: 110066. 